\title{
Geopolitics of Global Energy Transformation and Territorial Dynamics of Energy Transition in South America
}

\author{
Ana Lía Guerrero
}

${ }^{1}$ Universidad Nacional del Sur, Department of Geography and Tourism, Bahía Blanca, Province of Buenos Aires, Argentina.

\begin{abstract}
This article aims to analyze global and regional South American contexts of the on-going energy transition, from a territorial and geopolitical energy perspective. Multiscalarity is adopted as a methodological strategy that allows analyzing social actors beyond a single scale of political action. It is complemented with a bibliographical review and interpretation of reports prepared by several international organizations. The conclusions confirm that on a global scale the trend is to achieve decarbonisation through actions by States, society and companies that mitigate climate change. At the South American regional scale, energy transition is more complex, as it seeks to contribute to improve the quality of life of society with a strategy of diversification of electricity matrix - focused on gas resources and hydroelectric energy - but unsolved, historical and geopolitical conflicts, added to social, economic and political issues, make it difficult to achieve a deeper and more sustainable regional energy transformation.
\end{abstract}

Keywords: Geopolitics, territory; energy; energy transition; South American.

São Paulo. Vol. 24, 2021

Special Issue: Energy territories

DOI: http://dx.doi.org/10.1590/1809-4422asoc20200026r3vu2021L4DE 


\section{Introduction}

The existence on a global scale of a geopolitical and energy scenario of a multipolar, interdependent, dynamic and complex nature, shows an energy matrix that is in a period of transition / transformation from the simultaneous growth of the use of gas (conventional and unconventional) and of new renewable energies (wind and solar). In this context, the study of geopolitical and energy orders, from a multiscalar territorial perspective, allows contextualizing the South American energy reality in its interaction with the global scale.

This article proposes a geopolitical and territorial perspective of energy, as it is in the territory where it becomes visible how globalizing processes provide new logics in local, national or regional spaces - with their own specificities - with conflicts that are understood and acquire meaning based on the historical trajectory of the specific territories and the individuals who inhabit them. From this territorial perspective, the New Political Geography, with a scalar and relational approach, aims at the study of the State through power relations in space at different scales (GUERRERO, 2016). Moreover, the contributions of Geopolitics in general and Geopolitics of Energy in particular are highlighted.

Geopolitics requires the theoretical framework offered by Political Sciences, International Relations (power concept), Geography (vital space), and other sciences such as Economics (wealth and resources notions) and History (evolution and dynamics conceptions) (DALLANEGRA PEDRAZA, 2010, p.16). In particular, the Geopolitics of Energy seeks to analyze and understand the conflicts that arise in the use of energy resources, based on geographical factors associated with the availability for the development of transport routes and the construction of infrastructure, in addition to political and economic factors (HUTSCHENREUTER, 2008, p. 3).

From this dual perspective, different dimensions of the energy transition stand out, with advances and setbacks in the way in which each State joins, as, having the same resource, there are different paths to achieve the energy transition, and they depend on the historical trajectory, economic and technological circumstances in which each State finds itself, and that is why the results between regions differ.

The article aims to analyze the South American global and regional context, from a territorial and geopolitical energy perspective, through a multi-scalar and multidimensional approach that gives greater scope and complexity to the study of the current energy transition / transformation. The working hypothesis is that on a global scale the trend in central countries is to achieve decarbonization through actions by States, society and companies, which transform the energy system as a whole. At the South American regional scale, the energy transition is more complex, since it does not only seek to mitigate climate change but also aims to contribute to improving the quality of life of society, with a strategy of diversification of the electricity matrix - focused on the resources of the region like gas and hydroelectric power - but unresolved, historical and current geopolitical conflicts, added to social, economic and political issues, make it difficult to achieve a deeper and more sustainable regional energy transformation.

In relation to the applied methodology, multiscale is adopted as a methodological 
strategy that allows analyzing social actors beyond a single scale of political action. It is also complemented with a bibliographic review and interpretation of reports prepared by international organizations such as IRENA $(2018 ; 2019)$, OLADE $(2018 ; 2020)$, Bp (2019), IDB (2020), ECLAC (2019) among others.

The proposed scalar approach that considers scales as power mobilization arenas, together with the geopolitical and territorial view of energy, implies overcoming the localglobal dichotomy and proposing a broader and more flexible study, focusing particularly on the South American Region. The article is divided into three sections: 1) Contextualization: Parallelism between geopolitical orders and energy orders; 2) Global Scale: A dual energy transition on the way to a global energy transformation?; 3) Regional Scale: The energy transition in South America.

\section{Contextualization: Parallelism between geopolitical orders and energy orders}

This section analyzes the global geopolitical and energy context, from the perspective of spatialized multiscalar and trans-scalar power relations that occur between territory and energy over time, seeking to establish a parallelism between the different geopolitical and energy orders, in the framework of the proposal to analyze the energy transition from a territorial and geopolitical energy perspective.

The Geopolitical perspective is another way of approaching reality, its contributions are highlighted as a complementary analysis model with other studies and the consideration of the Territory as a territorial anchoring and not only as a productive enclave, because here, among others, there are resources and actors as main protagonists. The space is territorialized through voluntary processes of appropriation, control, domination, transforming the geographical environment into a social product due to the presence and creative human action that changes over time and unfolds strategies, actors and resources in an always dynamic game by power relations.

The geopolitical order refers to the way in which individuals, human groups, actors, institutions or power structures establish themselves in space in its multiple dimensions (economic, political, environmental, social and security), trying to influence the processes of taking decision, making their respective strategies prevail. In this sense, the world political system is the result of a series of historical processes, called world geopolitical orders that, in each of the historical periods, reflect the structure and distribution of power. Each of them is led by a power that establishes its hegemony and imposes the international norms to be followed, which are accepted and obeyed mostly by the other states (TAYLOR, 2002).

Consequently, world geopolitical orders, from a historical perspective of world space, respond in each period to historical changes that have occurred in the distribution of power. Phases of expansion, stabilization and decline occur through a succession of cycles of hegemony of dominant powers in the world system. From a territorial perspective, 
there is a spatial differentiation in the World System between the Center, constituted by the State that determines the rules for the articulation of power, and the Periphery, individualized as the set of dependent territories where growth is induced and subordinated to outside interests. At the beginning of the 21st century, the rebirth of China in the international context introduces new perspectives since economic, military and political power converge for the first time in a country other than the United States. This change raises the uncertainty if the future is heading towards a new multipolar world, or if, as other authors consider, a new G2 would be formed with the United States and China leading the world geopolitical order.

In this scenery, the Geopolitics of Energy is in close contact with Geoeconomics, as it focuses on the use made by the States of the natural resources they possess, as well as on the power relations established between the owners of the resource, the territories and the possible derived conflicts with their impacts on the territorial development. The appropriate context to analyze these changes in the Geopolitics of Energy is to know how, together with the world geopolitical orders, the different energy orders have evolved over time, since the search for control of energy resources has been a fundamental geopolitical axis through which political and economic power flow.

As Sánchez Albavera (2006, p.39) argues, every civilization has an "energy order, which implies an articulation between producers and consumers whose central axis of action, conciliation and conflict is a dominant energy source". The construction of a new world energy order, through a transformation of the energy system, is at the center of current conflicts that can be understood as positions in relation to the control of resources, since without energy there is no development.

Changes in energy orders occur through the so-called energy transition, which takes place over long periods of time - 40/130 years - and is related to the transition from an economy with a dominant source of energy and its corresponding technology to another (FOUQUET, 2012, p.3). However, it is also important to highlight the different duration between countries to carry out this process. The changes in energy civilization that humanity has undergone have implied, not only the availability of a new source of energy, but also the transition from an economy with a dominant source of energy and its technology to another, with a country that dominates it and exercises power.

In these transitions, it is observed the weight that hydrocarbons had, and still have, as a primary energy source, throughout history. In addition, they allow the identification of three main energy transitions that have occurred to the present day (GUERRERO, 2016). The first started in the XVIII century and involved the passage from firewood to the use of coal in the XIX century as the dominant source of energy and coincides with the First Industrial Revolution, centered in Great Britain.

The second was the shift towards the use of oil in the 20th century as the basis of economic activity, coinciding with the Second Industrial Revolution, centered in the United States, which allowed the displacement of Germany and England from power. The Middle East strengthened its position on a global scale since the main hydrocarbon supplier countries are located there, with prices set through the Organization of the 
Petroleum Exporting Countries (OPEC) since 1960, who can influence the oil market, if they decide reduce or increase their level of production.

The last energy transition in the 21st century shows a trend towards the use of gas as a substitute good, more abundant, with a lower price than oil and the least polluting of hydrocarbons. It is considered a bridge or transition fuel until a massive use of renewable resources can be developed. This resource long underestimated by oil companies becomes a fundamental element in the decarbonization process on a global scale. Thus, oil in particular and hydrocarbons in general, had an important geopolitical component from its inception, which remains until the present, due to its ability to influence energy security, economic development and climate change on a global scale.

In the future, the energy map of the XXII century will be redrawn with the rapid growth of renewable energies that will alter the power and influence of some countries and regions in relation to others, although it remains uncertainty whether this will be based on the development of renewable energies, hydrogen or nuclear fusion. Chart 1 shows in a comparative way, the existing similarities in the analysis of geopolitical and energy orders on a global scale.

Chart 1. Comparative Analysis of Geopolitical and Energy Orders, on a global scale, 2019

\begin{tabular}{|l|l|}
\hline \multicolumn{1}{|c|}{ Geopolitical Orders } & \multicolumn{1}{c|}{ Energetic Orders } \\
\hline $\begin{array}{l}\text { Complex and Dynamic Multipolar } \\
\text { Geopolitical Order }(G 7, G 8, G 20, G 2)\end{array}$ & $\begin{array}{l}\text { Complex and Dynamic Energy Order. } \\
\text { Gas and Renewables in simultaneous gro- } \\
\text { wth. }\end{array}$ \\
\hline $\begin{array}{l}\text { A more multilateral economic go- } \\
\text { vernance scheme with a diversity of } \\
\text { actors. }\end{array}$ & $\begin{array}{l}\text { More multilateral economic governance } \\
\text { scheme with a diversity of actors. Partici- } \\
\text { pation of non-OPEC countries (United } \\
\text { States, Brazil). }\end{array}$ \\
\hline $\begin{array}{l}\text { More geopolitically and militarily } \\
\text { unilateral (United States) }\end{array}$ & $\begin{array}{l}\text { More one-sided from the Geopolitics of } \\
\text { Energy. } \\
\text { The United States is the largest producer } \\
\text { of unconventional gas and oil; has reserves } \\
\text { of resources and mastery of fracking tech- } \\
\text { nology; exporter (LNG), does not belong } \\
\text { to OPEC. Ranked 2nd in wind and solar } \\
\text { power generation capacity (2017). }\end{array}$ \\
\hline
\end{tabular}


Trend towards a new bipolar world centered on China and the United States, called G2.
China is a technological leader in renewables: solar and wind power. It owns $71 \%$ of rare earths (wind turbines) and is the largest producer of silicon (photovoltaic energy).

Trend towards a new bipolar world centered on CHINA and the USA. Both countries will be future central players, due to the technological development already achieved.

Source: Guerrero 2019

In short, having reserves of renewable or non-renewable energy resources, as well as their production and consumption, generates complex and dynamic dependencies among countries, with interactions between geopolitical and energy orders at different scales. Since energy is the basis of economic development, power relations derived from the vulnerability and / or dependency that occur between producing and consuming countries are established.

\section{Global Scale: A Dual Energy Transition on the way to a Global Energy Transformation?}

At present, uncertainty is the scenario of the contemporary energy transition, in this context of changes in energy sources and changes in energy orders, an energy transition is taking place on a global scale and, in particular, in central countries. Comparing to transitions occurred so far, this one has the peculiarity that the trend is not towards a dominant energy source with a country that owns it, but it is led by the simultaneous development of gas (conventional and unconventional) and new renewable energies (wind and solar), and that is why the Bp report (2019) calls it dual energy transition.

However, even though the rate at which renewable energy enters the global energy system is faster than that of any other fuel in history, global CO2 emissions continue to rise, indicating the need for a demanding set of comprehensive political actions to achieve a substantial reduction in carbon emissions (Bp, 2019). In this sense, some examples of actions carried out by States, society and companies are then developed in point 2.2.

On the other hand, it is noted that there are differences in the population / resource relationship from one region to another, from one country to another, not only due to an irregular spatial distribution of resources, but also because consumption patterns differ due to the fact that the populations have reached different levels of satisfaction of their needs, as well as different levels of technological development that allow them to access the resource. In this sense, the report, Renewable Energy Policy Network for the 21st 
Century (Ren 21, 2018) mentions that it is only an electrical transition, since it is in that sector where the highest incorporation of renewable energies occurs (25\%), despite the fact that it only has $20 \%$ of the consumption, while, in cooling and heating, which is where the highest percentage of energy is consumed (it incorporates only $10 \%$ ), as is the case with transport, which represents $32 \%$ of consumption (incorporates only $3 \%$ ) with electromobility.

Finally, the International Renewable Energy Agency (IRENA, 2019), through the Global Commission on the Geopolitics of Energy Transformation, supported by Germany, Norway and the United Arab Emirates, generated a report that highlights that the contemporary energy transition at a global scale is not just a change from one fuel to another, as occurred in previous transitions, but there are different fuels in use joining different sectors, with different speeds in each country or region, therefore it is a much more complex and deeper transformation of the global energy system, which will have social, economic and political implications that go beyond the energy sector in particular. In this sense, it is proposed to point out that at present it would be more appropriate to use the term energy transformation, which contains these broader implications and involves a more complex and integrated scenario than the energy transition alone (IRENA, 2019).

\subsection{Changes in the dominant energy order}

Currently, changes occur that alter the dominant energetic order. The first of these occurs in the technology that allowed the United States, through fracking, to extract unconventional hydrocarbons, such as shale oil and shale gas (in an incipient way it is also being developed in Argentina). Likewise, the extraction of hydrocarbons in deep and ultra-deep waters of the pre-salt, through the development of its own technology in the case of Brazil. These States, not being part of OPEC, make decisions independent of those interests which implies a loss of decision-making power and influence of OPEC in general and of the Middle East in particular. (GUERRERO, 2016).

The second significant change that occurs today is in transportation, in particular with the growing market for liquefied natural gas (LNG) to which the South American Region joined in 2008. With the increase in the number of methane tankers and regasification vessels, the need arises to develop infrastructure such as regasification or liquefaction plants in different parts of the world, which enable countries to reduce their vulnerability and / or dependence on a single supplier. From the Geopolitics of Energy, the use of new resources and new technologies added to the changes in the transport of gas by sea, produce a geographical reconfiguration of the circulation of energy both on a global and regional scale through the conformation of new distribution networks that generate new facilities and new energy flows (with different producers and consumers), where the production of territory is expressed, specifically, in the construction of infrastructure, in the materialization of investments and in the re-functionalization of some of the existing ones (GUERRERO, 2016).

This situation expresses how, in the face of the challenges posed by energy transi- 
tions, the energy system rearranges and reorganizes energy flows according to the resources and obstacles that each historical period presents. The scenarios projected by different reports up to the year 2040 have one element in common, a peak in the consumption of fossil fuels around the year 2025 followed by a long and slow decline in their consumption, at the same time as there is a rapid increase in fuel consumption demand for renewable energy from the year 2050. This vision also coincides with the scenario proposed by Shell, which is the only one that extends until the year 2100 (SHELL SKY SCENARIO $2100,2018)$. For these scenarios to occur, the presence of different actors is necessary to motivate them.

\subsection{Current Changes from Society, Companies and States}

Some of the future changes are related to a combination of factors such as: low-cost natural gas, around $\$ 3$ per million Btu, social pressure to reduce air pollution by reducing carbon emissions, and increased participation of renewable energies in the energy matrix. The main actions to achieve these changes are carried out by society, companies and States, particularly in those with greater development.

From society, a social change is produced from below, with greater social awareness about the importance of sustainable development and the consequences of the use of fossil fuels, in relation to global climate change. Future generations have already been born and demand these changes, through various actions, such as those developed by the Swedish activist Greta Thunberg, who at the age of 16 started a school strike for the climate, which later led to a global movement in more of 100 cities in the world, called "Global Strike: Fridays for the future". Her voice has already been heard at the Summit on climate change (COP 24 and COP 25) and at the World Economic Forum. There she pointed out: "... I don't want them to have hope, I want them to be afraid and start acting."

From companies, changes are also observed both in technology and in the form of organization of companies. The case of Shell is an example of these changes, by 2030, it aims to have become the largest electricity company on the planet, through changes in technology and the form of organization, going from producing only oil to creating different dedicated divisions to the various ways of generating electricity, whether from less polluting fossil sources such as gas or renewable sources, creating integrated companies. The trend is towards low-carbon energy sources in order to cut its net carbon footprint in half by 2050 .

The company says "We see that the future group of customers will be much more decentralized (batteries in their basement, solar panels on the roof) and will need us to help them optimize the use of energy, not just supply it." They think that their future customers will not be passive consumers of electricity, but will be producers and consumers "prosumers" of electricity in an interconnected grid and will prepare for those changes.

Regarding the States, it is estimated that, in the year 2040, the two countries with the highest energy demand will be China and the United States (Bp, 2019). In the United 
States, during the presidency of Donald Trump, the existence of global climate change has been ignored and they withdrew from the Paris Agreement. However, its greenhouse gas emissions are at their lowest levels since 1991 (Bp, 2019). The exploitation of shale gas made it possible to reduce coal consumption and increase gas consumption in its energy matrix and made investments in renewable energies. In order to reduce greenhouse gas emissions, China consumes less coal and increases the import of LNG (34\% in 2018). Moreover, it increased the participation of renewable energies, installed photovoltaic plants with a capacity of 53 gigawatts, more than half of the world capacity. The change in China's fuel mix accounts for $80 \%$ of the downward revision of global coal consumption. China and the United States together represent 70\% of the growth in global gas consumption to replace coal (Bp, 2019).

In view of these changes made by the Society, the Companies and the States, renewable energies are at a time that seems to favor the possibility of overcoming the historical obstacle that were the costs of their production, through the application of incentives and subsidies for their development, together with technological changes and the change in social awareness about the environment, which favor them. However, the problem of intermittence and storage continues to limit their participation in the energy matrix.

From a geopolitical point of view, it is observed how the energy matrix changes and decarbonizes, but -the power and wealth it generates- remains in the hands of the same companies, who change their structure looking for new market niches in renewable energies, to exercise their control, no longer in the territorial enclaves where the resources are found, but in the domain of the technologies that allow them to exploit them, often with a vision of commodification of the electricity sector. In this sense, - both society and States - must be aware of the asymmetric power relations that exist with companies (GUERRERO, 2020).

It should be noted that in the South American Region the situation is more complex since there are other priorities in the States and society. First of all, the State must guarantee the population access to energy services, particularly for those with lower income. To do this, it depends on the operation and maintenance of the gas and electricity infrastructure, as well as the availability of various types of affordable fuels. In addition, to increase the participation of new renewable energies, it must be considered that the final cost of technology is linked to technical, regulatory, fiscal and energy policy factors and variables that stimulate these investments and develop their own technology, with the support of the states.

\section{Regional Scale: Energy Transition in South America}

In the global context developed in the previous sections, it is worth asking what are the territorial dynamics that are taking place in the South American Region? Are they in a process of energy transformation, in a dual energy transition or in an electrical transition? From a geopolitical and territorial view of energy, a more complex energy transition is observed in the South American Region with political and economic decisions that consider not only the region's own resources and care for the environment, but also its 
historical trajectory, its economic, political and social structure in order to improve the quality of life of the population.

According to the 2019 ECLAC report, the use of natural gas stands out in Latin America, which has been accompanied by a policy of its insertion in the energy matrix of the countries of the region. In South America in particular, except in the case of Uruguay and Paraguay, the rest of the countries have proven reserves of this resource that amount to 7,528 billion $\mathrm{m} 3$. The ratio between the volume of reserves and production $(\mathrm{R} / \mathrm{P})$, for the group of South American countries, shows a value of 42.1 years (slightly below the world average, of the order of 52.4 years), as reported Di Sbroiavacca et al (2019).

In relation to energy transition policies in the South American Region, the change that has already been made was from the use of oil towards a greater penetration of gas as a fuel for electricity generation, considering, also, the scarce presence of coal compared to the rest of the world regions. As a regional peculiarity, the weight of hydroelectric energy (conventional renewable energy) stands out. Thus, a diversification of energy sources is observed that goes in the same direction as on a global scale with a dual energy transition (gas and renewables) and in particular a change in the electricity generation matrix (electricity transition).

The following tables corroborate this assertion. According to the Energy Prospective report (OLADE, 2018, p. 384), the variation in the supply of primary energy between the South American energy matrix in 2016 and 2040 shows little variation in the percentage of hydrocarbons (Chart 2).

Chart 2. Comparative analysis of the changes in the primary energy matrix in South America between 2016-2040, in\%

\begin{tabular}{|c|c|c|c|c|c|c|c|}
\hline $\begin{array}{l}\text { Primary } \\
\text { Energy Ma- } \\
\text { trix in \% }\end{array}$ & @. & $\begin{array}{c}\sigma 0 \\
\tilde{\omega}^{2}\end{array}$ & 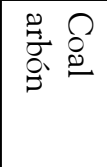 & $\begin{array}{l}\text { Wind, solar } \\
\text { and geothermal } \\
\text { energy }\end{array}$ & $\begin{array}{l}\text { Hydro } \\
\text { electric }\end{array}$ & $\begin{array}{l}\square \\
\square \\
\\
\vdots \\
0 \\
0 \\
\infty\end{array}$ & 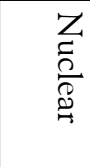 \\
\hline 2016 & 39 & 30 & 6 & 1 & 7 & 16 & 1 \\
\hline 2040 & 38 & 28 & 5 & 4 & 7 & 16 & 1 \\
\hline
\end{tabular}

Source: Guerrero, 2020; based on Prospectivas Energéticas, OLADE, 2018.

Regarding the changes in the electricity generation matrix, it can be inferred that, both in 2016 and in 2040, the largest sources of electricity production come from hydroelectricity and gas (Chart 3). In relation to other non-conventional renewable energy sources, the growing use of wind energy stands out in particular. 
Chart 3. Comparative analysis of the main changes in the electricity generation matrix in South America between 2016-2040, in\%

\begin{tabular}{|c|c|c|c|c|c|}
\hline $\begin{array}{l}\text { Electricity Gene- } \\
\text { ration Matrix as \% } \\
\text { of total electricity } \\
\text { generation }\end{array}$ & $\stackrel{Q}{\infty}$ & $\begin{array}{l}0 \\
0 \\
0\end{array}$ & 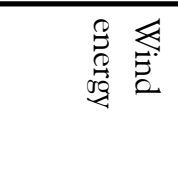 & 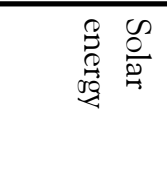 & $\begin{array}{l}\text { Hydro } \\
\text { electric }\end{array}$ \\
\hline 2016 & 28 & 7 & 3 & 0 & 44 \\
\hline 2040 & 30 & 6 & 12 & 3 & 37 \\
\hline
\end{tabular}

Source: Guerrero, 2020; based on Prospectivas Energéticas, OLADE, 2018.

The Energy Panorama of Latin America and the Caribbean 2020 (OLADE, November 2020), shows electricity generation in Latin America and the Caribbean in 2019, by type of source (Chart 4). It can be observed that sum of renewable sources is $57.8 \%$. As Alfonso Blanco Bonilla, director of OLADE argues "Ours is the area of the world with the highest proportion of renewable energy in its electricity mix" (AMERICA ECONOMY, 2018).

Chart 4. Electricity generation matrix in Latin America and the Caribbean by type of source in \%, 2019.

\begin{tabular}{|c|c|c|c|c|c|c|c|}
\hline 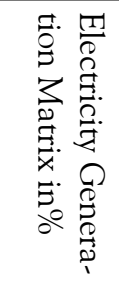 & 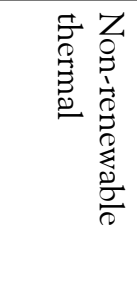 & 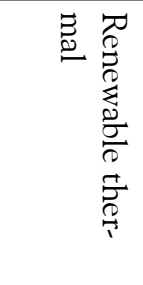 & 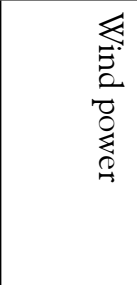 & $\begin{array}{l}0 \\
0 \\
0 \\
0 \\
0 \\
\stackrel{0}{0} \\
\stackrel{0}{0} \\
0\end{array}$ & 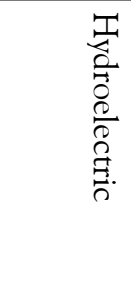 & 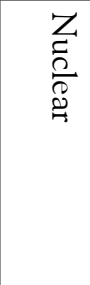 & 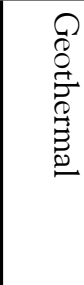 \\
\hline 2019 & 39,3 & 5,1 & 6,0 & 1,5 & 45,2 & 2,2 & 0,7 \\
\hline
\end{tabular}

Source: Guerrero, 2020; based on the Energy Panorama of Latin America and the Caribbean, OLADE, 2020

In short, the electricity matrix at the South American Region scale continues to depend on gas and hydroelectricity. It should be noted that prior to the search for gas integration, already in the 1970s and 1980s, the development of large hydroelectric dams had taken place from binational projects, such as Itaipú between Brazil and Paraguay; Yaciretá between Argentina and Paraguay and Salto Grande, between Argentina and Uruguay, which constitute the bases for regional electricity integration. At present, there is an increase in the participation of wind energy, among the new renewable energies. This fosters the diversification of the electricity matrix and strengthens energy security since hydroelectric energy is vulnerable to climatic variations such as droughts, which are increased by climate change. In addition, the South American electricity and gas 
subsectors have a deep relationship with each other since natural gas reserves are used as a source for electricity generation thanks to the technological advances of combined cycle turbines.

\subsection{Territorial dynamics of gas in the South American energy matrix}

Gas is a main component of the dual energy transition, as well as in the search for regional energy integration in general and gas in particular. In relation to the historical trajectory of the territory and its resources, during the period 2004-2019, various territorial dynamics occurred reflected in six short cycles, each characterized by changes in the location, in time and space, of possible gas supply centers, when facing supply conflicts between the countries of the region, leading to the question of whether there is real integration or only a gas interconnection. These conflicts began between Argentina and Chile in 2004, when production from the Loma de la Lata deposit in Neuquén (Argentina) began to decline. First, it appears as a conjunctural issue that later turns on a structural nature. The conflict in the search for solutions extends to the region, incorporating Perú, Bolivia, Venezuela and Brazil and then on a global scale with extra-regional actors such as Russia, Iran and China.

According to Guerrero (2016), in this expanded context, scenarios of cooperation and conflict overlap, which increases regional uncertainty regarding achieving energy integration. In 2005, an attempt was made to create a gas ring that incorporates gas from Peru (Camisea field) to Chile and Argentina. This project is prevented by historical and current geopolitical conflicts, existing between Chile and Peru due to the delimitation of the territorial sea. The same situation was repeated in 2006 when Argentina resumed the importation of gas from Bolivia, but with the explicit clause that not a molecule of that gas could be redirected to Chile, due to conflicts related to the loss of access to the sea in Bolivia.

Between 2006 and 2007, Venezuela emerged as a new supply alternative, through the so-called Great Southern Gas Pipeline that would run through Venezuela, Brazil, Uruguay and Argentina. It never came to fruition due to its infeasibility in technical, economic, legal and environmental aspects. In 2008, large hydrocarbon discoveries were made in deep and ultra-deep waters of the pre-salt in Brazil, which appeared as a new alternative solution to the conflict. However, it is impeded by problems of technological development and time for its extraction.

Since 2008, not finding a solution to supply problems, due to still unresolved geopolitical conflicts - which affect current decisions and not due to a shortage of reservesseveral countries in the region (Argentina, Chile, Brazil) seek to meet the gas demand in the domestic market through the installation of regasification plants that receive LNG, transported by sea from abroad.

Thus, the South American Region joined the global LNG market as an emerging market in 2008, despite an ideological and political alignment of governments that would suggest greater possibilities for energy integration. From a territorial energy perspective, 
it is observed that energy integration processes through the laying of gas pipelines, dominant in previous periods, favoring integration through long-term bilateral agreements, are neglected. In this sense, in 2007 the Margarita Island Summit was held (paradoxically known as the "First Energy Summit"), in which the Union of South American Nations (UNASUR) and the South American Energy Council were created, which, contrary to expectations, as Palestini (2016) argues, marks the beginning of the dissolution of South American energy regionalism.

Since 2008, from the point of view of Energy Geopolitics, in the South American Region the dependence on LNG imports has increased, with multiple suppliers and shortterm contracts and, as a consequence, there is less dependence on both Argentina and Brazil from Bolivian gas and Chile from Argentine gas. In turn, dependence on extraregional actors is increasing and South American regional energy integration is weakened, with empty gas pipelines and breach of agreements.

The discovery in 2012 of the Vaca Muerta formation (Argentina), with the second global reserves of shale gas and the fourth of shale oil, requires unconventional resource extraction techniques through fracking, which require capital and technology. The emerging production of these resources in 2019 allows the removal of the regasifier vessel from Bahía Blanca port and the installation of a liquefaction barge that exports some surplus shale gas production in the months of lower consumption. However, in 2021, in the framework of the Covid 19 pandemic, regasification vessels are hired again to settle in said port.

The following map, Figure 1, synthesizes and locates the main changes produced in the South American Region, in relation to the natural gas resource, the location of the reserves and the changes in transportation by gas pipelines or by sea as LNG. 
Figure 1. The South American gas network

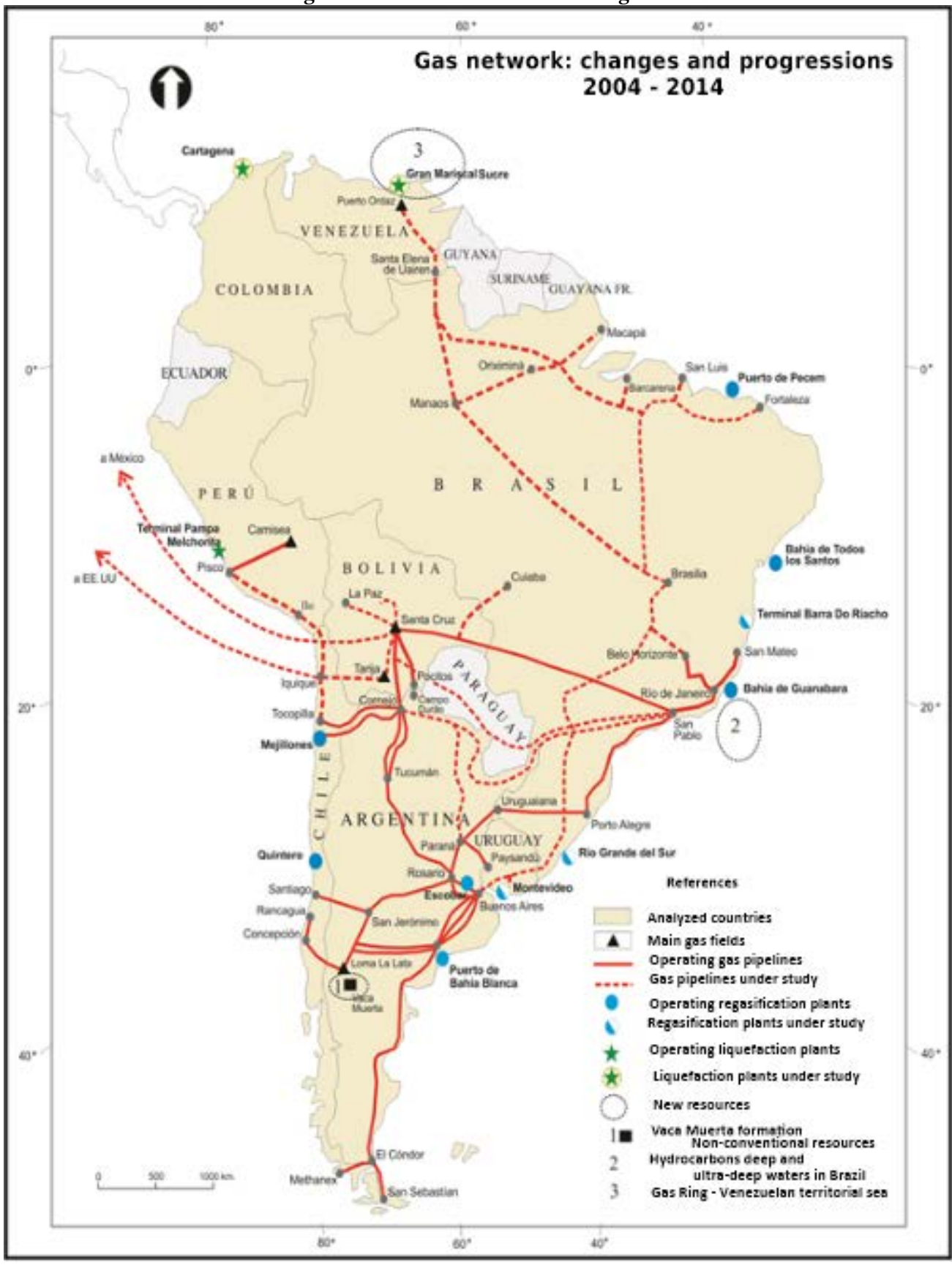

Source: Guerrero, 2016 


\section{The energy (dis) integration in South America is an obstacle to the regional energy transition}

Beyond the geopolitical and territorial issues described above, there is discussion among various authors about the real possibility of achieving energy integration and who exercises regional leadership, within the framework of the current energy transition. As Fuser (2020) argues, in addition to regional differences, changes in the global energy scenario have also hampered the progress of the South American energy integration project. In this sense, the 2008 economic crisis, which affected the developed countries more, implied a decrease in the consumption of LNG in Europe and the search for new markets, which fostered the incorporation of the South American Region as an emerging market.

With a more optimistic vision, Sabatella $(2018$, p.103) rescues that the gas integration process in South America has a rich and vast trajectory that does not seem exhausted. He states that, although the bilateral bonds went through significant difficulties and the multilateral initiatives of the post-liberal stage have failed, a state of regional disintegration in gas matters has not yet been reached and points out that, despite the exponential increase in extra-regional trade in LNG, up to and including 2015, the volume traded by gas pipelines remained close to half of the total volume.

Likewise, the entry of extra-regional actors is observed, who exert pressure according to their own interests. This is the case of China, whose economic growth has transformed the global and regional energy scene. Since its internal demand cannot be satisfied only with its own resources, the search for new sources of supply abroad generated that China invested US \$101,250 million in energy ventures in South America between 2005 and 2020, according to data from the China Global Investment Tracker (CGIT, 2020). Thus, the region became a space of dispute between China and the United States (leaders of the new geopolitical and energy order), the articulation capacity between regional actors was reduced and the leadership of Brazil diminished (FUSER, 2020, p.256).

As regards regional leadership, there are different positions. On the one hand, Nivalde de Castro, in an interview conducted by Arroyo (2013), argues that Brazil has all the conditions to lead the energy integration process, due to its strategic location as a meeting point for the main hydrographic basins of the continent, its shared border with 10 of the 12 neighboring countries in South America, its advanced and successful experience in the design of electrical power generation and distribution systems over long distances, the diversity of its energy matrix and the favorable financing conditions, via BNDES, of large-scale infrastructure projects.

On the other hand, Thauan dos Santos (2018) argues that beyond those characteristics of Brazil, Argentina and Bolivia, they play a central role in promoting regional energy integration, based on the fact that each has borders with five countries, abundant water resources and large-scale conventional and unconventional reserves, which place them in a strategic position to promote regional energy integration. He argues that proposals focused only on Brazil should be avoided and that regional energy integration planning should be joint and participatory. Furthermore, in order to prevent integration from being dependent (and vulnerable) to the political situation / internal ideology of 
the countries of the region, the particular needs of each country must be considered, to enable a long-term sustainable project.

In this sense, as argued by Levy et al (2020), there are still internal barriers that prevent regional energy integration - gas and electricity - that may arise from mistrust and uncertainty among the States of the region. This causes that they do not generate strong links between them and that this possible dependence is seen as a threat to their energy security. Furthermore, Castro, Rosental and Gomes (2011) highlight that energy integration faces resistance to its development, associated with factors such as institutional and regulatory asymmetries together with restrictions of a more political nature, derived from suspicions due to the loss of sovereignty or national autonomy, lack of physical infrastructure, as well as the lack of common planning for the expansion of energy systems.

Likewise, Thauan dos Santos (2018) concludes that up to this date there is no energy integration that considers joint regional energy planning; that worries about the harmonization of regulatory frameworks; that brings together regional producers, distributors and consumers in an integrated and participatory way and considers that regional energy integration should be (re) thought about considering renewable energies, given the wind, solar and hydroelectric potential of the region and therefore, favoring the transition energetic.

Furthermore, Guerrero (2020) argues that the interrelation between political, economic and energy integration can be seen in the stagnation of projects to plan and promote the infrastructure and energy network in South America during the different cycles of progressive and liberal governments of the last decade. Consequently, South America emerges as a fragmented space in national economies oriented to achieve its own energy security, rather than as an integrated space that seeks to achieve a sustainable energy transition, supported by common energy policies, a variety of renewable and nonrenewable resources, existing infrastructure. and numerous agreements signed between the countries of the region.

In this context, from a South American geopolitical perspective, coinciding with Palestini (2016), the region shows signs of stagnation in achieving energy integration and, as Sabatella (2018) points out, the current UNASUR crisis projects a pessimistic outlook for the relaunch of new multilateral initiatives within the South American Energy Council.

\section{Final considerations}

After analyzing the Geopolitics of global and regional energy transformation, as well as the territorial dynamics of integration and energy transition in South America, it is important to recognize the different speed of change of the world energy system between sectors (most important electricity), countries (China, United States, Germany) and regions (South America).

In the South American Region, as Sabatella (2018) points out, a state of regional disintegration has not yet been reached in gas matters and progress is being made towards greater diversification of the regional energy matrix, mainly in the electricity matrix, sup- 
ported by energy hydroelectric power and the incorporation of new renewable energies such as wind and solar.

In this sense, the various energy transition policies in the South American region have been characterized by the use of gas - as a less polluting fossil fuel - as a bridge between the past, when the use of oil and coal decreased, favoring its penetration as a fuel for electricity generation, and the future, until new renewable energies are used on a larger scale.

In addition, in relation to the electricity matrix, the weight of hydroelectric energy (conventional renewable energy) is a regional particularity, which makes it more vulnerable to climate variations, as in the case of droughts, caused by climate change. In order to reduce this dependence on climate and increase energy security, new renewable energies such as wind and solar are expanding their share, supported by government subsidies, lower production costs and advances in storage technologies that open up new opportunities to think about a deeper energy transition.

The lack of joint initiatives for energy cooperation and integration were identified as obstacles to the development of the regional energy transition, particularly because of the regional situation since 2016, due to the political changes that have occurred and the loss of weight of UNASUR (COSIPLAN) that affected integration projects. It is worth asking whether in the future, the States of the region will make joint decisions prioritizing investments that favor energy transition, sustainable development and integration rather than the rapid monetization of reserves and the commoditization of the energy sector, as sought by companies.

From the standpoint of the Geopolitics of Energy, the South American region currently operates as a periphery subordinated to external decisions. Although the region possesses abundant renewable and non-renewable natural resources, it lacks common political projects and there is a regional leadership vacuum that is reflected in its dependent insertion in the world system and in the fragmentation within the region, as a consequence of current and historical geopolitical conflicts still unresolved, which have an impact on energy supply decisions. In addition, there is distrust among the countries of the region to cede sovereignty, as well as different positions on which countries should exercise regional leadership, added extra-regional actors that exert pressure according to their own interests. Energy does not appear then as an element of integration, but of power for those who possess it and, therefore, as a factor of dispute.

From the point of view of energy transition, coinciding with Nivalde de Castro in Arroyo (2013), the States are responsible for promoting, directly or indirectly, investments in the energy sector, fostering greater dialogue between the different actors and generating the necessary political mechanisms that lead companies to undertake these changes. However, the political context does not favor major long-term initiatives, as there is no convergence of strategic agendas among Mercosur countries (SANTOS, 2018). Society itself must demand these changes and become aware of the importance of the transition to clean energy sources.

In the short and medium term, there are challenges for the energy policies of the 
countries of the region, which have differences in their socioeconomic and technological starting points as well as in their institutional structures; therefore, the results will be different in each country on the road to achieving a deeper and more sustainable energy transformation, in the absence of joint initiatives for regional energy cooperation and integration, in the context of the weakening of the South American Energy Council, UNASUR and Mercosur.

In a global context full of uncertainties, predicting how the energy transition/ transformation will evolve is a complex challenge, but it would be desirable for the energy system to reach a dynamic and flexible interdependence and complementarity. The South American energy transition poses an even greater challenge, given the need for a more integrated and complex approach that seeks not only to mitigate climate change but also to contribute to improving the society's quality of life, avoid energy poverty and achieve a just transition.

\section{References}

ARROYO, Navel. "Entrevista com Nivalde de Castro: 'La integración de América del Sur pasa por priorizar las inversiones”. Energía, Bolivia. La Paz, 7 de junio de 2013. Disponible en: http://www.provedor.nuca.ie.ufrj.br/eletrobras/estudos/arroyo1.pdf Acceso en:18 de abril de 2021.

BRITISH PETROLEUM. Bp Statistical Review of World Energy 2019 [White paper]. Disponible en:_https://www.bp.com/content/dam/bp/businesssites/en/global/corporate/pdfs/ energy-economics/statistical-review/bp-stats-review-2019-full-report.pdf Acceso en: 25 diciembre 2019.

CASTILlO, T. et al. Panorama Energético de América Latina y el Caribe: Prospectivas Energéticas, Ecuador: Organización Latinoamericana de Energía (OLADE), 2018. Disponible en: http://biblioteca.olade.org/opac-tmpl/Documentos/old0416b.pdf. Acceso en: 2 abril 2019.

CASTRO, N.J., ROSENTAL, R., GOMES, V.J.F. "La Integración del Sector Eléctrico en América del Sur: Características y beneficios”. V SISEE - Seminário Internacional do Setor de Energia Elétrica, Brasília: Fundação Alexandre de Gusmão, p.31-50, 2011. Disponible en: http://provedor.nuca.ie.ufrj.br/eletrobras/estudos/castro138.pdf Acceso en:18 de abril de 2021.

DALLANEGRA PEDRAZA, L. Teoría y metodología de la Geopolítica. Hacía una geopolítica de la "construcción de poder". Revista mexicana de Ciencias Políticas y sociales, México, v. LII, n. 210, p.15-42, 2010.

DEUTSCHE WELLE Energías renovables ganan protagonismo en matriz energética de Latinoamérica. América Economía, 2018. Disponible en: https://www.americaeconomia. com/negocios-industrias/energias-renovables-ganan-protagonismo-en-matriz-energetica-delatinoamerica. Acceso en: 5 abril 2019. 
DI SBROIAVACCA, N., DUBROVSKY, H., NADAL, G. Y CONTRERAS, R. Rol y perspectivas del gas natural en la transformación energética de América Latina: aportes a la implementación del Observatorio Regional sobre Energías Sostenibles (Documento de Proyectos LC/TS.2019/23). Naciones Unidas CEPAL. 2019. Disponible en: https://repositorio. cepal.org/handle/11362/44596 Acceso en: 15 diciembre 2019.

FOUQUET, R. Past and prospective energy transitions: insights from history. Energy Policy, v. 50, p.1-7, 2012.

FUSER IGOR Y ALMEIDA FERREIRA ABRÃO, RAFAEL Integração energética na américa do sul: perspectivas, impasses e obstáculos Brazilian Journal of Latin American Studies Cadernos Prolam/USP,. Edição Especial: Relações China - América Latina e Caribe. v. 19, n. 37, p. 240-267, out. 2020 .

GUERRERO, A. La Nueva Geopolítica de la Energía en la Región Sudamericana. Tendencias, actores y conflictos en la industria del gas. 2016. Tesis (Doctorado en Geografía) - Departamento de Geografía y Turismo, Universidad Nacional del Sur, Bahía Blanca, 2016. Disponible en:http:// repositoriodigital.uns.edu.ar/bitstream/123456789/2944/1/Tesis\%20Doctoral\%20Guerrero.pdf. Acceso en: 20 de marzo 2019.

GUERRERO, A. Repensar la integración energética sudamericana frente a la incertidumbre de la integración regional y la transición energética global. Aportes para la Integración Latinoamericana, n. 42, p.1-29, 2020.

HUTSCHENREUTER, A. Las compuertas geopolíticas del siglo XX. Buenos Aires: Centro Argentino de Estudios Internacionales (CAEI), 2008. Disponible en: https://es.scribd.com/ document/87112343/Caei-Las-Compuertas-Geopoliticas-Del-Siglo-XX . Acceso en: 23 marzo 2019.

IRENA 2019. A New World. The Geopolitics of the Energy Transformation. Masdar City, Abu Dhabi, 2019. Disponible en: https://www.irena.org/publications/2019/Jan/A-New-WorldThe-Geopolitics-of-the-Energy-Transformation . Acceso en: 2 abril 2019.

LEVY, A., TEJEDA, J., Y DI CHIARA, L. Integración eléctrica regional: oportunidades y retos que enfrentan los países de América Latina y el Caribe (Monografía del BID, 742). Banco Interamericano de Desarrollo. 2020. Disponible en:_http://dx.doi.org/10.18235/0002129 Acceso en: 20 diciembre 2020.

REN21, Renewables 2018 - Global Status Report: Renewable Energy Policy Network for the 21st Century, Paris, 2018. Disponible en: https://www.ren21.net/wp-content/uploads/2019/05/ GSR2018 Full-Report English.pdf. Acceso en:2 abril 2019.

RÍOS ROCA, A. Rol del Gas Natural en el Desarrollo Económico y Social de América Latina y el Caribe, Ecuador: OLADE, 2013. Disponible en: http://www.olade.org/wp-content/ uploads/2015/08/Rol-gas-natural-desarrollo-ec-soc.pdf. Acceso en: 3 abril 2019.

SABATELLA, I. ¿GNL vs. gasoductos? Tensiones en el proceso sudamericano de integración gasífera, Ciclos, vol. XXV, n. 51, p. 85-106, 2018. 
SANTOS, T. Regional energy security: re-evaluating concepts and policies to promote energy integration in Mercosur. Tese (doutorado) - UFRJ/ COPPE/ Programa de Planejamento Energético, 2018.

OLADE. Panorama Energético de América Latina y el Caribe, Ecuador: Organización Latinoamericana de Energía (OLADE), 2018. Disponible en: http:/www.olade.org/publicaciones/ panorama-energetico-de-america-latina-y-el-caribe-2018/. Acceso en: 2 abril 2019.

OLADE Panorama Energético de América Latina y el Caribe, Ecuador: Organización Latinoamericana de Energía (OLADE), 2020. Disponible en: http://www.olade.org/publicaciones/ panorama-energetico-de-america-latina-y-el-caribe-2020/. Acceso en: 20 diciembre 2020.

PALESTINI, STEFANO Energía de baja intensidad: gobiernos, mercados e instituciones en el regionalismo energético de América del Sur. Caderno CRH, Salvador, v. 29, n. SPE 03, p. 107 $123,2016$.

SÁNCHEZ ALBAVERA, F. América Latina y la búsqueda de un nuevo orden energético mundial. Nueva Sociedad, n. 204, p.38-49, 2006.

SHELL SKY SCENARIO 2100, La Haya, 2018. Disponible en: https://www.shell.com/energy-and-innovation/the-energy-future/scenarios/shell-scenario-sky.html. Acceso en:4 abril 2019.

TAYLOR, P; FLINT, C. Geografía política: economía-mundo, estado-nación y localidad. Madrid: Trama, 2002. 


\section{Ana Lía Guerrero}

$\checkmark$ analiaguerrero06@gmail.com

ORCiD: https://orcid.org/0000-0002-4275-1385
Submitted on: $22 / 04 / 2020$

Accepted on: 09/05/2021

2021;24e:00263

How to cite: GUERRERO, A. L. Geopolitics of Global Energy Transformation and Territorial Dynamics of Energy Transition in South America. Ambiente \& Sociedade. São Paulo, v. 24, p. 1-22, 2021. 


\title{
Geopolítica da Transformação Global da Energia e Dinâmicas Territoriais da Transição Energética na América do Sul
}

\author{
Ana Lía Guerrero
}

São Paulo. Vol. 24, 2021

Dossiê especial:

Territórios da Energia
Resumo: $\mathrm{O}$ artigo tem como objetivo analisar o contexto global e regional sul-americano da transição energética através de uma abordagem territorial e geopolítico da energia. A multiescalaridade é adotada como estratégia metodológica que permite analisar os atores sociais para além de uma única escala de ação política, complementado com uma revisão bibliográfica e interpretação de relatórios preparados por várias organizações internacionais. As conclusões alcançadas confirmam que à escala global a tendência é a descarbonização através de ações dos Estados, da sociedade e das empresas que mitiguem as alterações climáticas. $\mathrm{Na}$ escala regional sul-americana, a transição energética é mais complexa, busca contribuir para a melhoria da qualidade de vida da sociedade com uma estratégia de diversificação da matriz elétrica - com foco em recursos de gás e energia hidrelétrica - mas não resolvida, geopolíticas acontecimentos, histórica e atuais, somados às questões sociais, econômicas e políticas, dificultam o alcance de uma transformação energética regional mais profunda e sustentável.

Palavras-chave: Geopolítica; território; energia; transição energética; América do Sul

Como citar: GUERRERO, A. L. Geopolítica da Transformação Global da Energia e Dinâmicas Territoriais da Transição Energética na América do Sul. . Ambiente $\&$ Sociedade. São Paulo, v. 24, p. 1-21, 2021.

DOI: http://dx.doi.org/10.1590/1809-4422asoc20200026r3vu2021L4DE 


\title{
Geopolítica de la Transformación Energética Global y Dinámicas Territoriales de la Transición Energética en Sudamérica
}

\author{
Ana Lía Guerrero
}

São Paulo. Vol. 24, 2021

Dossier especial:

Territórios de Energía
Resumen: El artículo tiene por objetivo analizar el contexto global y regional sudamericano, de la transición energética, desde una perspectiva territorial y geopolítica de la energía. Se adopta la multiescalaridad como estrategia metodológica que permite analizar los actores sociales más allá de una única escala de acción política. Se complementa con revisión bibliográfica e interpretación de informes elaborados por diversos organismos internacionales. Las conclusiones alcanzadas confirman que a escala global la tendencia es alcanzar la descarbonización mediante acciones de Estados, sociedad y empresas, que mitiguen el cambio climático. A escala regional sudamericana, la transición energética es más compleja, busca contribuir a mejorar la calidad de vida de la sociedad con una estrategia de diversificación de la matriz eléctrica -centrada en el recurso gas y la energía hidroeléctrica- pero conflictos geopolíticos irresueltos, históricos y actuales, sumados a cuestiones sociales, económicas y políticas, dificultan alcanzar una transformación energética regional más profunda y sostenible.

Palabras-clave: Geopolítica; territorio; energía; transición energética; Sudamérica.

Como citar: GUERRERO, A.L. Geopolítica de la Transformación Energética Global y Dinámicas Territoriales de la Transición Energética en Sudamérica. Ambiente \& Sociedade. São Paulo, v. 24, p. 1-21 , 2021.

DOI: http://dx.doi.org/10.1590/1809-4422asoc20200026r3vu2021L4DE 